\title{
SISTEM KEKERABATAN ORANG BUGIS \\ DI SULAWESI SELATAN \\ (SUATU ANALISIS ANTROPOLOGI - SOSIAL)
}

Wija Na Bati in Bugis Kinship System in South Sulawesi

A Social Anthropology Analitical

Oleh: Eliza Meiyani*

*Dosen Kopertis Wilayah IX (UIM Makassar)

Alamat: Jl. Bung, Tamalanrea Makassar

Email: elizameivani@yah6o.co.id

\begin{abstract}
Abstrak
Sistem kekerabatan masyarakat Bugis Bone memiliki struktur bati na wija sebagai pranata sosial yang menjadi wadah pembentukan knalitas masyarakat untuk mendukung sistem sosial dan sistem budaya masyarakat yang harmonis. Masyarakat Bugis Bone sejak dahulu telah menjadikan bati na wija sebagai sarana yang membentuk sistem pemerintahan efektif dan efisien. Membantu pemimpin dan pemuka masyarakat yang berkualitas dan maтри menjadi pioner dalam membangun sistem kerajaan yang besar yaitu kerajaan Bone, Kerajaan Gowa dan Kerajaan Luwu. Namun, saat ini peran wija na bati mulai tergeser berangsur-angsur ke pembentukan kualitas individual, masyarakat dan pemimpin pada pendidikan dan harta benda menjadi tolak ukur. Bergesernya peran wija na bati tersebut sebagai akibat lemahnya ketahanan budaya orang Bugis-Bone untuk menjadikannya sebagai sarana pembentukan kualitas individual, kemimpinan dan kualitas masyarakat. Peranan sistem kekerabatan yang menyimpan nilai-nilai kekerabatan yang dianut pada masa lalu tidak lagi menjadi sarana yang efektif membentuk struktur sosial masyarakat Bugis- Bone yang harmonis. Meskipun demikian, mash ada sebagian kecil kelompok masyarakat Bugis-Bone yang masih konsisten menggunakan nilai-nilai kekerabatan sebagai sarana pembentukan kualitas individual, pemimpin dan masyarakat, teruma pada daerah-daerah yang masih terdapat orang-orang yang menjunjung tinggi tradisi budaya masyarakat Bugis-Bone yang diyakini sebagai tradisi yang sudah dianut oleh para pendahulunya.
\end{abstract}

Kata Kunci: Wija na Bati: Antropologi-Sosial

\section{Abstract}

In Bugis Bone kinship system, bati na wija structure is social institution to establish communtiy quality to support harmonius social and cultural system. Since long time, Bugis Bone community has made bati na wija as an effective means to form effective and effecient government systems. It could help the local figures and leaders to establish great kingdom system, such as that of Bone, Gowa and Luwu. However, the role of wija na bati has shifted gradually to emphasize on individual quality where wealthy and education level become a parameter. This shifting is due to the Bugis Bone weakness to maintain its own culture. Kinship system laden with kinship values has decreased its effectiveness toform harmonious Bugis Bone structure. Right now, there are only a few who still hold this tradition.

Key words : Wija na Bati, social anthropology

\section{LATAR BELAKANG}

$\mathrm{S}$ alah satu produk budaya manusia adalah perkawinan. Perkawinan merupakan suatu pranata sosial yang sangat penting dalam masyarakat dan merupakan pembentukan sistem sosial dan jembatan dalam pembentukan kekerabatan. Dalam antr.opologi, kata pranata atau institusi sama sebutannya dengan unsur kebudayaan.' Jika perkawinan merupakan unsur kebudayaan, maka melalui tulisan ini akan menjelaskan status kekerabatan seseorang berdasarkan wija na bati. Bahkan, wija na bati dapat menjadi acuan untuk menentukan apakah seseorang termasuk dalam jaringan kekerabatan tertentu atau bukan dan sebagai acuan dalam menentukan stutus sosialnya dalam masyarakat.

Sistem kekerabatan berdasarkan wija na bati, terikat oleh norma dan nilai-nilai sosial budaya yang dijadikan acuan dalam perkawinan. Aturan atau norma 
tersebut terangkum dalam panggadereng (ade, siri, rapang, wari, ). Dianutnya aturan, norma disebabkan karena perkawinan sebagai pranata sosial, didalamnya terdapat penetapan-penetapan status kekerabatan, terutama dalam menentukan derajat darah keturunan sebagai simbol status sosial.

Derajat darah dalam sistem kekerabatan tertentu, juga dapat mempengaruhi posisi seseorang dalam aktivitas sosialnya. Pengaruh itu tampak dalam acaraacara tertentu, seperti, perkawinan, kelahiran, kematian, dan pengangkatan sebagai tokoh masyarakat. Bahkan, derajat darah dapat menentukan stratifikasi sosial, dan jaringan kekerabatannya. Itulah sebabnya sehingga para ahli sosiologi mengasumsikan bahwa terbentuknya stratifikasi sosial erat kaitannya derigan pelembagaan sosial itu sendiri yang dijadikan sarana masyarakat dalam bertindak dan berinteraksi. Karena itu, ada hubungan fungsional struktural antara stratifikasi sosial dengan piranti sosial (perkawinan) dimana dalam proses pelembagaan diikat oleh nilainilai budaya masyarakatnya.

Selain itu, nilai-nilai budaya yang terdapat dalam wija na bati juga berfungsi sebagai simbol dalam kehidupan masyarakat Bugis. Sebagai simbol, ia dapat menjadi sarana budaya lokal untuk melekatkan harmonisasi hubungan sosial (social relationship) antara individu baik dalam lingkungan kerabat sendiri maupu di luar kerabat.

Niai-nilai ideal itu terdapat dalam sistem kekerabatan yang menurut konsep wija na bati sebagaimana asumsi teoretis beberapa ahli, seperti, dikemukakan oleh C. Kluckhon bahwa "setiap sistem nilai budaya dalam setiap kebudayaan itu terdapat lima masalah dasar dalam kehidupan manusia, yakni; 1) hakekat hidup, 2) hakekat karya, 3) hakekat kedudukan, 4) hakekat hubungan manusia dengan lingkungannya, dan 5) hakekat hubungan manusia dengan manusia. ${ }^{2}$

Dalam perkawinan masyarakat Bugis-Bone masih sangat dipengaruhi oleh hukum adatnya. Dalam lapisan anqkarung, misalnya status lapisan sosial berdasarkan wija atau bati masih diperhitungkan. Masih sering dilakukan kebiasaan menelusuri keturunan yang disebut maccuccung bati. Penelusuran ini terutama memeriksa secara saksama apakah termasuk kategori wija atau bati fgeneologisj. Konsekuensi dari penelusuran tersebut menimbulkan fenomena simbolik dalam masyarakat yaitu penentuan stratifikasi sosial melalui cara 'mencuri darah' (mennau dara) dengan jalan membuat silsilah yang dihubungkan seseorang anakkarung sebagai nenek atau buyutnya. Fenomena ini merupakan fakta dalam masyarakat Bugis-Bone, khususnya dalam acara perkawinan, pemilihan kepada desa.

Selanjutnya, studi tersebut menunjukkan bahwa studi tentang wija na bati sebagai sistem kekerabatan dalam masyarakat Bugis-Bone sangat penting sebagai suatu kajian antropologi, khususnya antropologi-sosial, baik dari aspek kepentingan akademis maupun kepentingan praktis dalam mempertahankan dan melestarikan nilai nilai luhur yang terkandungdi dalam sistem kekerabatan. Jika hal ini tidak mendapat perhatian, maka tidak menutup kemungkinan keunikan dan kekhasan abbatireng dan ampijangeng sebagai sistem kekerabatan masyarakat Bugis-Bone terancam punah hingga tertelan oleh pengaruh budaya globalisasi.

Dewasa ini dalam masyarakat Bugis Sulawesi Selatan, khususnya masyarakat Bugis Bone, pembentukan sistem kekerabatan berdasarkan wija na bati memiliki banyak fungsi yaitu fungsi pembentukan struktur sosial dan fungsi pembentukan stratifikasi sosial. Namun, patut disayangkan para ahli antropologi, khususnya para peneliti antropologi-sosial menaruh perhatian secara serius terhadap fenomena pembentukan sistem kekerabatan berdasarkan pola wija na bati pada masyarakat Bugis Bone khususnya dan masyarakat Bugis pada umumnya.

\section{DIMENSI KEKERABATAN DALAM PERS- PEKTIF ANTRO-POLOGI-SOSIAL}

Sistem kekerabatan merupakan salah satu pranata sosial yang tidak dapat dipisahkan dari kehidupan ummat manusia. Asumsi ini dibangun dari konsep pemikiran Wilken yang mendeskripsikan bahwa pada hakikatnya kehidupan manusia berasal dari suatu komunitas kecil (keluarga) yang di dalamnya terdapat lebih dari satu individu sebagai anggota kelompok. Pembentukan kelompok masyarakat manusia dimaksud bermula dari keluarga kecil yang terdiri dari ayah, ibu dan anak yang membentuk sistem kekerabatan tertentu. Sistem kekerabatan yang diperkenalkan teori Wilken pada mulanya disebut sebagai sistem kekerabatan'patriliner yang menempatkan salah satu anggota kekerabatan sebagai

Koentjaraningrat, Pengantar Umu Antropologi. Jakarta: Rineka Cipta 1981, hal. 191. 
pemimpin (kepala keluarga). Asal mula sistem kekerabatan ini tampaknya bersifat universal dan menjadi salah satu pranata sosial yang mengikat semua umat manusia sampai saat ini. Hasil kajian para antropologi sosial dan kebudayaan menunjukkan suatu kecenderungan tunggal pada kehidupan ummat manusia bahwa ummat manusia dipersatukan oleh warisan biologi yang sama ${ }^{3}$. Kesamaan sifat tersebut menunjukkan bahwa manusia memiliki satu tradisi kehidupan yang berbeda dengan makhluk lain (hewan dan tumbuh-tumbuhan) dalam proses perkembangannya.

\section{PENDIDIKAN KELUARGA}

Salah satu aspek yang terkait dengan kajian antropologi-sosial adalah sistem kekerabatan BugisBone, adanya pelembagaan pendidikan keluarga sebagai pranata sosial yang dapat menjadi sarana pelembagaan kembali nilai-nilai sosial pendahulu.

Aspek pendidikan keluarga sebagai salah satu pranata sosial dalam masyarakat mempunyai fungsi sosial di dalam pelembagaan dan pelestarian nilai-nilai budaya masyarakat yang dianut, diperjuangkan dan dipertahankan oleh komunitas tertentu sebagai produk yang mengikat masyarakat tersebut. Salah satu aspek kependidikan yang menjadi sasaran analisis adalah pelembagaan pendidikan melalui bati na wija sebagai sarana untuk mewariskan nilai-nilai kekeluargaan yang dipertahankan secara turun temurun. Nilai-nilai pendidikan keluarga yang terdapat dalan sistem kekerabatan Bugis-Bone dalam hal bati dan wija adalah pelestarian atau pelembagaan nilai pendidikan keluarga dalam hal pembentukan kekeluargaan yang baik. Pembentukan kekeluargaan yang baik dimaksud dalam bahasa bugis " sarekuangmenggi ripoleanggi wija atau ampijangeng to malebbi".Nilai ini merupakan nilai budaya masyarakat Bugis pada umumnya, termasuk masyarakat Bugis-Bone. Artinya, setiap keluarga Bugis-Bone membawa misi kekerabatan yaitu hendaknya senantiasa menjunjung tinggi kebaikan dalam keluarga, karena keluarga adalah tempat pertama dan utama bagi segala aspek kehidupan, bahkan beberapa orang, keluarga adalah kunci sukses dan menentukan kehidupan pada masa kini dan masa akan datang. Agar upaya tersebut dapat berhasil, diperlukan pelestarian pelembagaan kembali nilai tersebut yang pada akhirnya dapat mengangkat, mempertahankan dan meningkatkan nama baik keluarga secara keseluruhan.

Menurut catatan Lontarak, pada masa pemerintahan Raja Bone ke 29 (1857-1860) mendengungdengungkan petuah dalam bidang pendidikan keluarga yaitu "Rioloi Napatiroang, Ritengngai Naparagaraga, Rimonri Napianpiri, Yang artinya: Di depan sebagai contoh di Tengah sebagai partisipan dan Di Belakang sebagai Pengawas. Kajaolaliddong penasehat dan duta keliling kerajaan Bone dalam catatan Lontarak yang mengatakan bahwa "Aja mulampirianggi ada tomaccae nasaba mupabbiringeng mitu naissenni alena. Beberapa ungkapan. tersebut mendorong agar setiap anggota kerabat mempunyai dasar untuk bertindak baik dalam lingkungan keluarga maupun dalam bermasyarakat. Oleh sebab itu, dimensi kependidikan dalam keluarga melalui bati dan wija, bukan hanya sebagai simbol atau kebanggaan kekerabatan semata, tetapi tetap memelihara dan mewariskan nilai-nilai dan jasa dan pengabdian pendahulunya.

\section{KUALITAS MASYARAKAT}

Esensi utama kajian antropologi-sosial terhadap sistem kekerabatan berdasarkan abbatireng dan ampijangeng adalah pembentukan kualitas masyarakat. Pengertian tentang masyarakat menunjukkan suatu pemahaman bahwa setiap kelompok manusia (masyarakat) selalu terdapat hubungan antara individu yang satu dengan individu lainnya. Setiap hubungan antar individu di dalamnya terdapat interaksi sosial yang bersifat fungsional, langsung atau tidak langsung, yang membentuk suatu kesatuan sosial yang utuh. Pengertian tersebut membangun suatu pemahaman bahwa dalam suatu masyarakat memerlukan suatu kesadaran sosial sesama anggota masyarakat yang terwujud melalui interaksi sosial. Melalui kesadaran itu setiap anggota kelompok akan bertindak sesuai dengan nilai-nilai kesatuan yang terhentuk baik melalui pranata-pranata sosial yang ada maupun pada norma sosial yang berlaku. Salah satu pranata sosial yang

Lihat Simon Coleman dan Helen Watson. 2005. Pengantar Antropologi. Nuansa (Anggota IKAPI) Cet. Pertama, Ujung PandangBandung. h.79.

Hasil wawancara dengan Abu Hamid, tgl. 10 Maret 2008 di Makassar.

Konstruksi berfikir ini didasarkan pada asumsi teoritis Ralp Linton bahwa " dasar-landasan setiap masyarakat adalah kelompok individu individu, Kelompok ini merupakan bahan mentah, yang dapat dijadikan titik tolak untuk mengembangkan suatu masyarakat. Faktor hakikat berdirinya suatu masyarakat adalah apabila perserikatan individu berlangsung secara lama sehingga daya penyatu (integratif) yang akhirnya akan mentrasformasikan kelompok menjadi masyarakat. ibid, hi 19. 
terbentuk dalam masyarakat adalah sistem kekerabatan yang merupakan bawaan alamiah setiap ummat manusia.

Fungsi utama sistem kekerabatan dalam pembentukan kualitas masyarakat adalah menjaga pranata sosial agar selalu terpelihara agar dapat berfungsi sesuai dengan tujuan yang sesuai nilai-nilai setiap kelompok kekerabatan. Dalam tradisi masyarakat Bugis Bone, sistem kekerabatan memiliki banyak fungsi. Fungsi-fungsi tersebut antara lain, fungsi perekatan kekeluargaan atau "assiajingeng", fungsi penyesuaian kehendak sesama anggota kerabat atau "assituruseng abbatirreng". Fungsi-fungsi yang disebutkan tersebut merupakan fungsi sistem kekerabatan dalam rangka pembentukan kualitas masyarakat.

Beberapa istilah yang menjadikan setiap orang tetap patuh dalam kelompoknya sebagaimana warisan pendahulu dalam beberapa ucapan atau "pappaseng to Hold" yaitu "padecengngi ada adammu nasdba adaemitu mattungka tau", diartikan bahwa yang menjadi setiap individu itu baik ditentukan oleh perkataan-perkataan baiknya atau seseorang dikatakan ditentukan karena ucapan-ucapan baiknya. Selain itu, dikenal pula pesan orang terdahulu yaitu "Atinna tauwe diataneng-tanengi" artinya, hanya hati seseorang dijadikan sebagai dasar penilaian seseorang. Beberapa pesan orang terdahulu tersebut dianut oleh setiap individu dalam tradisi orang Bugis Bone sehingga kualitas masyarakat Bone saat itu bermartabat.

\section{RFALITAS SOSIAL SISTEM KEKERABATAN}

Realitas sosial suatu sistem kekerabatan erat kaitannya dengan analisis terhadap struktur-struktur sosial dan hubungan-hubungan sosial antar pranata dalam masyarakat. Terbentuknya hubungan-hubungan antar pranata sosial dalam masyarakat menjadi penting dalam persfektif antropologi sosial karena dalam hubungan-hubungan antar pranata sosial terdapat gerak yang dinamis yang menjadi indikator adanya pertumbuhan dan pergerakan pranata-pranata sosial secara simultan dan bersinergi.

\section{Stratifikasi Sosial Orang Bugis Bone}

Membicarakan tentang stratifikasi sosial suatu masyarakat dirasakan penting terutama untuk mengetahui dan mencari latar belakang pandangan hidup atau sifat sifat yang mendasari kebudayaan dari suatu masyarakat. Lebih jauh dari itu, dengan mengetahui pelapisan masyarakat dapat diungkapkan hubungan-hubungan kejadian dalam masyarakat yang menyangkut tingkah laku segenap kegiatan dalam masyarakat termasuk kegiatan dan tingkah laku politiknya.

Dalam masyarakat Bugis Bone pembentukan stratifikasi sosial tidak dapat dilepaskan dari adanya pengaruh peran atau sosok individu yang mempunyai kelebihan dari' orang lain. Dalam pembentukan stratifikasi Bugis Bone berlaku prinsip stratifikasi yaitu adanya pembentukan hirarkhi yang secara turun temurun berlaku pada setiap kelompok masyarakat. Hasil penelitian dalam Kitab Lagaligo menunjukkan bahwa dalam masyarakat Bugis Bone pembentukan stratifikasi sosialnya berdasarkan asumsi mitos to manurung yang pada prinsipnya menganut dua jenis manusia yaitu " manusia yang "berdarah putih" yang merupakan keturunan dewata, serta mereka yang 'berdarah merah" yang tergolong orang biasa, rakyat jelata, atau budak. ${ }^{6}$

Munculnya tokoh mitologis to-manurung dan keturunannya, yang oleh wasyarakat Bugis percaya mempunyai darah putih, tampaknya merupakan faktor utama terbentuknya pelapisan masyarakat. Jika dilihat dari sudut itu, maka masyarakat Bugis Bone terbagi dalam beberapa lapisan atas dasar kemurnian darah bangsawan yang ada pada meraka. Bahkan, ada ungkapan Raja Lapatau Matanna Tikka Matinro-E ri Nagauleng (Raja Bone ke XIV) menyatakan bahwa bahwa: "Wekkapitupi no anek eppoko arung mopf". Ungkapan ini menunjukkan bahwa tujuh turunan anak raja di Bone masih membawa dara ana 'arung sampai derajat ketujuh. Raja Lapatau Matanna Tikka Matinro-E ri Nagauleng adalah anak kemanakan "Latenritatta" Arung Palakka almarhum, bersaudara seibu-bapak dengan ibunda Baginda yang bernama "wemappolobangkeng" cucu dari "Latenriruwa" Raja Bone ke11 MatinroE ri Bantaeng. Adapun struktur kekerabatan Raja Lapatu Matanna Tikka MatinroE ri Nagauleng.

Menurut Lontara, susunan masyarakat Bone disebutkan sebagai berikut:

Lihat Christian Perlas. 2006. Manusia Bugis. Forum Jakarta - Paris: Jakarta ., h. 192.

Wawancara dengan Abu Hamid tanggal 22 April 2008 di Makassar. Abu Hamid seorang peneliti kebudayaan Bone sejak tahun 1974. 
"Naiya abbotirenggE ri Bone, abbupunggeng nengngi pakkana, Mula-mulanna ata, maduanna maradeka, amatellunna ata' arung sule, maeppana wija mappajung, malimanna to lebbiE, maenenna ama 'Eppone mappajungE.

Ungkapan Lontara tersebut menunjukkan bahwa dalam masyarakat Bugis-Bone telah terbentuk stratifikasi sosial yang telah menjadi pranata sosial yang terbentuk sejak dahulu. Pembentukan stratifikasi sosial tersebut menunjukkan bahwa dalam sejarah peradaban masyarakat pada umumnya terdapat tratifikasi sosial yang terbentuk karena adanya peran dari masing masing strata dalam masyarakat.Terbentuknya pelapisan sosial tersebut merupakan realisasi dari klasifikasi berdasarkan dara (abbatireng atau ampijangeng) atau keturunan sebagai unsur primer. Adapaun dasar stratifikasi yaitu:

1. Wij a (keturunan) ana' eppona mappaj ungngngE, ialah keturunan anak cucu Raja, menurut garis lurus dari Raja ke-XV.

2. Wija mampajung, ialah keturunan Raja-raja sebelum Islam dan sebelum menjadi Raja La Patau Matanna Tikka, Raja Bone ke-15. Keturunan Raja XV ini temasuk golongan keturunan "ana'eppona mappajungngngE'

3. Wija to' lebbi, ialah keturunan orang-orang mulad, yakni famili-famili dari ibu-bapak, La Patau Matanna Tikka.

4. Wija Anakkarasula, ialah anak-cucu Aru Lili (penguasa-penguasa) distrik), sebelum daerah tersebut menggabung diri pada kerajaan Pusat.

5. Wija To Maradeka, ialah keturunan orang-orang merdeka, biasa juga disebut Tosama;

6. Wij a Ata, ialah keturunan hamba.'

Keenam lapisan sosial itu terdiri atas tersebut terbentuk berdasarkan tradisi masyarakat Bugis Bone yang sudah dilembagakan masyarakat sebagai pranata sosial yang senantiasa menjadi acuan untuk menentukan status dan peran dalam masyarakat. Menurut Abu Hamid bahwa:

"Masyarakat Bugis membeda-bedakan manusia menurut tinggi rendahnya keturunan. Ukuran satu-satunya ialah soal darah atau keturunan sebagai unsur primair untuk itu perlu dibedakan terlebih dahulu macam-macam keturunan yaitu:

(1.1) Wija (keturunan) ana' eppona mappajungngnge, ialah keturunan anak cucu Raja, menurut garis lurus dari Raja Ke-XV.

(1.2) Wija mappajung, ialah keturunan Raja-Raja sebelum Islam dan sebelum menjadi Raja La Patau Matanna Tikka, Raja Bone ke XV Keturunan Raja XV ini termasuk golongan keturunan 1.1. di atas.

(1.3) Wija Tole'bi ialah keturunan orang orang muda, yakni famili-famili dari ibu-bapak La Patau Matanna Tikka.

(1.4) WijaAnakarussala, ialah anak cucu Aru Lili (penguasa-penguasa distrik), sebelum daerah tersebut menggabungkan diri pada kerajaan pusat

(1.5) Wija To Maradeka, ialah keturunan orangorang merdeka, biasa juga disebut Tosama Wija Ata, ialah keturunan hamba. ${ }^{10}$

\section{Kelompok Kekerabatan}

Konsepsi abbatireng dan ampijangeng sebagai inti dari sistem kekerabatan menurut orang Bugis Bone merupakan pranata sosial yang menjadi sarana budaya dalam mendukung pertumbuhan dan perkembangan sistem sosial yang mandiri dan lestari. Sebagai komponen sistem sosial, kekerabatan dalam wujud abbatireng pada mulanya difungsikan sebagai sarana untuk mendapatkan anggota keluarga yang berkualitas baik. Secara praktis, konsep ini dalam konteks antropologi sosial digunakan dalam acara-acara tertentu seperti, acara perkawinan sebagai pintu utama pembentukan dan perluasan sistem kekerabatan yang pada hakikatnya merupakan membagunan pertalian keluarga antara satu keluarga dengan keluarga lainnya melalui pintu perkawinan. Pertalian keluarga melalui perkawinan membangun suatu asumsi kekerabatan bahwa seseorang dapat membedakan secara jelas dan tegas kerabat dan bukan kerabat. Dari asumsi tersebut dibangun prinsip-prinsip yang sifatnya umum bahwa pertalian keluarga merupakan suatu keniscayaan ada dalam kehidupan setiap orang.

* Suriadi Mappangara, 2004. Kerajaan Bone dalam Sejarah Politik Sulawesi Selatan Abad XIX, Dinas Kebudayaan dan Pariwisata Provinsi Sulawesi Selatan, Makassar., h. 36.

'Lihat Abu Hamid. 2002. Budaya Politik dan Kepemimpinan di Sulawesi Selatan. Makassar: Dinas Kebudayaan dan Pariwisata Sulawesi Selatan., h. 34

'"ibid 
Bahkan stratifikasi sosial sebagaimana sistem pelapisan sosial tersebut sudah tidak dijumpai secara ekstrim dalam masyarakat Bugis Bone. Memudarnya sistem pelapisan sosial tersebut disebabkan karena adanya perubahan sikap masyarakat Bone terhadap sistem kekerabatan yang pernah berlaku. Umumnya masyarakat Bugis Bone tidak lagi secara ekstrim menggunakan lapisan-lapisan sosial yang pernah ada sebagai dasar penentuan status sosial yang mem-pengaruhi interaksi sosial sesama anggota masyarakat. Kalau dahulu, antara lapisan sosial hanya dapat berhubungan atau berinteraksi dengan sesama lapisan sosialnya, walaupun kadangkadang dengan lapisan sosial di luar stratanya secara terbatas. Namun, saat ini antara lapisan strata sosial menurut sistem kekerabatan tidak lagi menjadi penghalang. Bahkan, interaksi sosial tertentu, seperti, perkawinan sudah tidak lagi menggunakan prinsip-prinsip pelapisan sosial berdasarkan stratifikasi sosial menurut pola "abbatireng" dan "ampijangen". Mereka anggota kekerabatan secara longgar dapat mencari jodoh di luar stratanya atau lapisan sosialnya. Anak Mattola misalnya, sebagai lapisan pertama dapat saja kawin dengan anak to sama (orang biasa) yang termasuk dalam lapisan ketiga.

\section{KESELARASAN DAN HARMONISASI SO- SIAL DALAM SISTEM KEKERABATAN}

Salah satu tujuan yang ingin dicapai dalam pelembagaan pranata-pranata sosial adalah ter-bentuknya sistem sosial yang baik dan harmonis. Tujuan ini merupakan tujuan akhir dari semua pranata sosial yang ada dalam masyarakat baik melalui hubungan antarapranata, tindakan-tindakan sosial, interaksi-interaksi antarpranata." Dalam proses pelembagaan tersebut peran invidu atau manusia sangat menentukan. Manusia atau individulah yang menjadi aktor dalam tindakan sosial dan interaksi sosial. Terselenggaranyahubungan-hubungan antar pranata ditentukan oleh aktornya atau manusianya. Ada pernyataan yang mengungkapkan bahwa "manusia baru dapat dikatakan sebagai manusia yang sebenarnya, bila ia ada dalam masyarakat".

\section{Fungsi Membina Individu Menjadi Makhluk Sosial}

Tradisi masyarakat Bugis Bone mengenal istilah "wari-asiajingeng" yang didalamnya terdapat panggadereng yang dijadikan sebagai acuan dalam bertingkah laku semua anggota kekerabatan. Pentingnya menjaga kualitas sistem kekerabatan tampak dalam pandangan responden menyatakan bahwa :

"Makkedatopi to-matoae, atutuiwi atimmu, anggolona, aja' muammenassanggi ri maja 'e padammu tau, apa' mattantu, iko matti maja' mu'ni madecemmuna gau'mu, apa riturungeng ritu gau' madecengnge ri-ati maja 'e, de 'sa nariturungeng ati madeceng ri gau' maja 'e, aga nakko maja 7 atimmu, lettu 'i ri to rimonrimu ja'na"m.

Ungkapan pendahulu (to-matoae) tersebut menunjukkan betapa pentingnya kualitas individual setiap anggota yang termasuk dalam kekerabatan atau assiajingeng dalam sistem kekerabatan orang Bugis Bone. Menurunya kualitas anggota baik secara pribadi dan kelompok (keluarga) akan menurunkan juga kualitas kekerabatan. Itulah sebabnya sehingga dalam tradisi Orang Bugis Bone proses pelembagaan atau pelestarian sistem nilai dan prinsip kekerabatan yang terdapat dalampangadereng ditradisikan mulai sejak anak masih bayi.

Sebagai akibat banyaknya perubahan dalam masyarakat, banyak sistem kekerabatan tidak dapat mempertahanya nilai-nilai kekerabatan. Pada saat ini, nilai-nilai kekerabatan masa lalu mendapat tantangan dan tuntutan. Tuntutan dimaksud terkait dengan kebutuhan dan trend masyarakat global yang melahirkan nilai-nilai baru. Untuk menciptakan suasanayang serasi dan selalu sesuai dengan nilai-nilai tradisi diperlukan pembinaan bagi semua anggota kekerabatan menjadi anggota masyarakat (makhluk sosial) sesuai dengan karakter orang Bugis Bone, yang mempertahankan nilainilai pangadereng dalam rangka menciptakan keharmonisan dalam masyarakat. Dalam kaitan itu, setiap interaksi sosial dalam lingkungan masyarakat hams senantiasa menjunjungtinggi nilai-nilai dan prinsipprinsip yang dianut secara kolektif. Setiap anggota kekerabatan yang termasuk keluarga abbatireng atau ampijangeng wajib menjadi menjaga nama baik kekerabatnya dengan selalu memperhatikan nilai-nilai dan prinsip yang dianut komunitasnya.

\section{Fungsi Pembentukan karakter Individual dalam Sistem Sosial}

Berdasarkan pengamatan di lapangan tampak bahwa masyarakat Bugis Bone pada umumnya telah mendapat pengaruh yang sangat kuat dari budaya luar

\footnotetext{
" Lihat Koentjaraningrat. 1990. Pengantar Ilmu Antropologi, Edisi Baru, Rineka Cipta, Bandung, Oktober, h. $166-167$.

Wawancara dengan Andi Muallim, tgl. 12 Desember 2007 di Makassar.
} 
sehingga berpengaruh pada kualitas individu. Kuatnya pengaruh nilai-nilai budaya luar (modern) tersebut tampak pada lunturnya sistem nilai kekerabatan yang pernah dianut oleh orang Bugis Bone. Orang Bugis Bone saat ini tidak lagi secara penuh menganut secara ekstrim sistem kekerabatan sebagaimana yang pernah dianut oleh para pendahulunya. Kalau dahulu (dalam era Kerajaaan Bone) dikenal adanya stratifikasi sosial yang didasarkan pada status dan peran dalam sistem pemerintahan sebagaimana pada zaman kekuasaan Raja Bone. Penetapan posisi seseorang berdasarkan prinsip "abbatirenna" dan " ampij agennna" sudah tidak lagi menjadi dasar acuan seseorang untuk memperoleh status sosial dalam masyarakat. Bahkan, pengangkatan seorang pemimpin, terutama dalam bidang pemerintahan tidak lagi menjadikan konsep abbatireng dan ampijangeng menjadi syarat utama. Meskipun demikian, dalam pranata sosial lain, seperti, perkawinan prinsip "abbatireng" dan "ampijageng" masih menjadi dasar untuk memasukkan seseorang dalam sistem kekerabatannya.

Dalam mencari nafkah, misalnya, seseorang tidak segan-segan menggunakan 'abbatireng' dan 'ampijangeng' sebagai cara untuk mendapatkah kemudahan dalam menjalankan usahanya atau mengusulkan suatu proyek tertentu. Penggunaan kedua konsep tersebut dalam lapangan ekonomi dan politik pada prinsipnya bukan pada tempatnya, akan tetapi dari segi fungsi sosialnya menjadi sarana untuk menghilangkan problem -problem dalam interaksi sosial. Meskipun demikian, peralihan fungsi prinsip kekerabatan tersebut dapat menciptakan hubunganhubungan sosial menjadi dinamis sehingga tatanan yang diharapakan. Terciptanya hubungan -hubungan sosial yang dinamis akan mengarah pada hubungan sosial yang dapat menumbuhkan ketertiban dalam sistem sosial. Kondisi ini merupakan prasyarat utama terbentuknya suatu masyarakat sebagaimana konsep masyarakat yang dikemukakan oleh Krech, Crutchfield dan Ballachey mengemukakan masyarakat: "a society is that it is an organized collectivity of interacting people whose activities become centered around a set of common goals, and who tend to share common beliefs, attitudes, and modes of action" 13 Konsepsi masyarakat tersebut jika ditelusuri pembentukan masyarakat menurut ada-ada To Riolo atau To Matoa memiliki persamaan.
Persamaan itu tampak dalam kalimat yang diajukan oleh Arungpone kepada Kajaolaliddo yaitu:

"aga tanrana cinna matena tana-marajae, Kajao, Makkedai Kajaolaliddo, iana tanrana cinna matena tana-marajae Arumpone, linga-lingae, maduanna, nakko teai ri pakainge arungnge, matellunna, de 'e to macca ri wanuae, maeppa 'na nakko naenrekiwi waramparang tomabbicarae, malimanna wedd pada gau'e ri lalempanna, maenenna, tennamasewi atanna arungmangkau 'e

Berdasarkan pandangan Kajaolaiddo tersebut, masyarakat tidak lain adalah kolektivitas interaksi manusia yang terorganisasi dalam kegiatannya terarah pada sejumlah tujuan yang sama, dan berkecenderungan memberikan keyakinan, sikap, dan bentuk tindakan yang sama. Konsep masyarakat lebih dicirikan oleh interaksi, kegiatan, tujuan, keyakinan, dan tindakan sejumlah manusia yang sedikit banyak berkecenderungan sama. Pengertian tersebut menunjukkan secara nyata bahwa dalam suatu sistem sosial terbangun hubungan-hubungan sosal dengan berfungsinya pranata sosial merupakan pendukung terciptaknya suatu aktivitas yang positif antara individu sehingga terbentuk suatu ikatan-ikatan sosial yang mempunyai tujuan, tindakan yang sama. Bagi orang Bugis Bone, saat ini baik di perkotaan maupun di pedesaan umumnya menjadikan 'abbatireng" dan 'ampijangeng' tidak hanya sebatas pada predikat yang pemaknaannya menurut persepsi pandahulu, akan tetapi saat persepsi bervariasi. Bagi orang Bugis Bone, ada yang mempersepsikan abbatireng atau ampij angeng hanya sebagai simbol kekerabatan. Pengetahuan mereka tentang kekerabatan hanya sebatas pelalacakan asal -usul kekerabatannya (mencari abbatireng' dan 'ampijangeng') dan hanya sebagai sarana untuk memperkenalkan diri sebagai anggota kekerabatan. Sedangkan bagi orang awam hanya menjadi penanda atau simbol bahwa seseorang termasuk abbatirenna to deceng, atau ampijangenna to malebbi. Kedua persepsi masyarakat tersebut tidak berpengaruh dalam interaksi sosialnya. Artinya, ketika seseorang diketahui abbatireng' dan 'ampijangengnna" status sosial seseorang tidak naik juga tidak turun.Lainnya halnya pada masa lalu, ketika itu prinsip abbatireng" dan 'ampijangeng' menjadi

Lihat H.Nursid Sumaatmadja. 2000. Manusiadalam Konteks Sosial Budaya dan Lingkungan Hidup. Alfabeta: Bandung., h. 34.

Mattulada. 1975. Latoa :Suatu Lukisan Analitis terhadap Antropologi-Politik Orang Bugis, Disertasi, Universitas Indonesia, Jakarta., h. 106. 
dasar utama penentuan status dan peran seseorang dalam masyarakat. Dalam kaitan itu, tampak bahwa ada pergeseran nilai-nilai budaya secara ekstrim, terutama sejak hapusnya sistem Kerajaan Bone oleh pemerintahan Hindia Belanda, dan sejak kemerdekaan Republik Indonesia menjadi negara kesatuan. Gejala ini tampak menggelobal pada hampir semua sistem budaya di beberapa kerajaan di Sulawesi Selatan. Pergeseran persepsi dan fungsi tersebut juga berpengaruh terhadap efektivitas pembentukan pranata-pranata sosial. Meskipun demikian, nilai-nilai dan prinsip-prisnip sistem kekerabatan dimaksud tidak hilang secara keseluruhan, karena dikalangan masyarakat masih ada golongan yang menganggap bahwa nilai-nilai tersebut masih dianut kuat oleh sebagian orang Bugis Bone sebagaimana pendapat responden Andi Amiruddin menyatakan bahwa:

"saat ini abbatireng" dan 'ampijangeng' masih ada dalam ingatan masyarakat Bugis Bone, karena dalam setiap penulisan nama masih dicantumkan pada nama gelar tertentu yang sesuai dengan abbatireng' dan 'ampijangengnna, hanya saja tidak ditonjolkan sebagai suatu gelar yang harus dibanggakan". ${ }^{15}$

Berdasarkan pandangan tersebut dapat dinyatakan bahwa secara teoretik konsepsional, pergeseran nilainilai budaya, termasuk pranata sosialnya suatu bangsa atau komunitas disebabkan banyak faktor. Salah satu faktornya adalah adanya perubahan sistem pemerintahan yang dianut. ${ }^{16}$ Kecenderungan teoretis tersebut tampak dalam jelas dalam perubahan nilai-nilai budaya masyarakat Bugis Bone.

Proses sosialisasi sistem kekerabatan sebagai pangadereng kepada individu dalam sistem sosial akan berlanjut selama mereka masih terikat dalam suatu sistem sosial. Umumnya sistem sosial menjadi wadah serta agen penggerak individu menjadi pribadi yang diharapkan sesuai dengan tuntutan perkembangan zaman. Oleh sebab itu, dalam proses sosialisasi nilainilai kekerabatan, akan terjadi proses internalisasi, aktualisasi diri yang semakin meningkatkan mutu individu menjadi pribadi yang manusiawi. Deskripsi idealis kualitas individu yang diharapka dari pelembagaan kembali nilai dan prinsippangadereng (Ade 'E) dalam sistem sosial tampak dalam Gambar sebagai berikut:

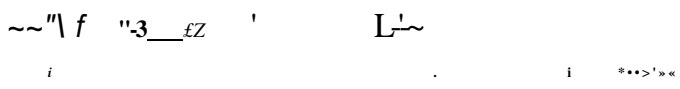

Gambar Korelasi antar komponen pranata sosial dalam pembentukan kepribadian untuk mendukung sistem sosial dalam masyarakat

Gambar tersebut menunjukkan bahwa pembentukan kepribadian Individu dalam masyarakat yang terdiri dari perasaan, pikiran, kemampuan berkomu-nikasi dan berperilaku pada umumnya, yang ia tidak hanya didukung oleh satu komponen pranata sosial, melainkan banyak komponen pranata sosial yang dapat mempengaruhi pribadi dan sistem sosial. Kemampuan pribadi yang demikian, tidak dapat dilepaskan dari suasana kondusif yang diciptakan oleh masyarakat lingkungan melalui lembaga-lembaganya, baik lembaga informal (keluarga), maupun lembaga nonformal (masyarakat, society, community), dan lembaga formal (sekolah, instansi, pemerintahan). Keajekan masyarakat membina warganya menjadi warga yang tangguh, kreatif, penuh gagasan, etos kerja tinggi, dan proaktif, sangat dipengaruhi oleh kepedulian semua pihak, bagaimana menempatkan nilai-nilai dan prinsipprinsip panggaderang (Ade 'E) dalam arti yang sebenarnya untuk mengembangkan pribadi yang dicita citakan tersebut.

\section{Fungsi Penselarasan Nilai Budaya dalam Sistem Sosial}

Hasil observasi menunjukkan bahwa terjadi konflik antara nilai-nilai budaya baru dengan nilai-nilai budaya lama yang bersandar pada nilai-nilai dan prinsip-prinsip sisitem sosial yang terdapat dalam pangadereng $\left(A d e^{\prime} E\right)$. Adanya perbedaan ini karena besarnya perubahan dalam masyarakat yang mengakibatkan antara nilai budaya lama dengan nilai budaya baru ada yang tidak singkron sehingga menimbulkan ketidak selarasan peri laku, antara generasi muda yang banyak menerima nilai-nilai baru dengan generasi tua yang masih mempertahankan nilai-nilai lama sebagaimana yang terdapat dalam pangadereng (Ade 'E). Hasil

Wawancara tanggal 25 Maret 1997 di Bone

Robert H. Lauer. 1993. Persfektif Tentang Perubahan Sosial. Rineka Cipta., h. 394-397. 
penelitian berdasarkan responden Andi Amiruddin, P.S.H. (60thn) menyatakan bahwa:

"Bagi generasi muda ada yang sudah tidak mematuhi lagi nilai-nilai pangadereng yang dahulu dijunjung tinggi, akan tetapi sekarang nilai pangadereng seperti, meminta "taZ>e" jika lewat di hadapan orang tua sudah jarang lagi hormat kepada guru, kepada orang yang dituakan tidak dapat dirasakan lagi sebagai kebiasaan para pendahulu".

Berdasarkan hal tersebut tampak bahwa terjadi pergeseran nilai-nilai lama dalam masyarakat. Apa yang dianggap baik oleh pangadereng dulu sekarang sudah bukan lagi, yang menentukan nilai baik dan buruk tidak lagi dimonopoli oleh pangadereng (Ade 'E) akan tetapi juga bersumber dari rasionalitas dan budaya baru yang berasal dari luar. Banyaknya sumber nilai budaya tersebut sering menimbulkan konflik dalam masyarakat sehingga diperlukan upaya penselarasan nilai-nilai budaya agar masyarakat terhindar dari konflik-konflik yang menyebabkan masyarakat tidak tertib.

Peran dan fungsi sistem kekerabatan seagai salah satu pranata sosial memegang peranan penting dalam penselarasan nilai budaya dalam masyarakat. Peran dan fungsi ini pada prinsipnya merupakan fungsi primer "dalam sistem sosial. Dikatakan fungsi primer oleh karena kekerabatan memiliki banyak anggota yang terdiri dari individu-individu baik terdapat dalam golongan "abbatireng" (keturunan) maupun yang tergolong dalam kelompok "ampijangen". Semua individu dapat dipastikan mereka masih terikat dengan nilai-nilai moral kekerabatan sehingga pengaruh budaya luar dapat diselaraskan melalui pendekatan kekeluargaan. Dalam banyak hal, hasil observasi menunjukkan bahwa banyak konflik sosial yang terjadi dalam masyarakat, baik dalam keluarga maupun diluar keluarga diselesaikan melalui pendekatan kekerabatan. Beberapa nilai-nilai pangadereng yang dapat diperankan oleh kekerabatan dalam menselaraskan nilai-nilai budaya lama dengan nilai-nilai budaya baru sebagaimana ada To-Riolo atau ada To-Matoa yaitu:

"Makadaetopi to-matoe ', atutuiwi atimmu ' anggolona, aja' muamminasanggi ri 'maja 'e padammu tau' apa' mattantu, iko matti maja' mu'ni madeceng muna gau'mu, apa riaturungeng $r i$ tu gau madecenggge ri ati ma'jae, de 'na nariturungeng ati madecenngnge ri ga 'u majae, aga nakko maja 'I atimmu, lettui ri turimunrimu

Lihat Mattulada,op.cit.h.11O
Ungkapan tersebut mengandung nilai nilai kebaikan yang terfokus pada moralitas individual. Semau aspek yang mendatangkan keburukan manusia akan dicel atau tidak disukai oleh semua orang. Setiap nilai budaya mengadung unsur kebaikan sehingga bersifat universal. Selain itu, penekanan moralitas dalam ungkapan tersebut ditujukan kepada individu sehingga ketika setiap individu melaksanakan nilai-nilai tersebut akan disambut atau tidak akan terjadi penolakan oleh karena memiliki nilai yang sama. Oleh karena itu, pada hakikatnya munculnya ketidakselarasan dalam masyarakat bersumber dari seberapa besar setiap individu melaksanakan nilai-nilai budaya tersebut. Bahkan, tanpa memiliki sifat sifat yang demikian, individu dalam kehidupan sosial, akan terpencil, terisolasi dan tersisihkan. la akan sukar berkomunikasi dengan lingkungan di sekitarnya. Padahal, komunikasi ini merupakan sarana yang amat bermakna bagi pengembangan potensi diri, hubunganhubungan dan interaksi-interaksi sosial. Dalam hal percepatan penselarasan nilai-nilai budaya dengan menggunakan sistem kekerabatan diperlukan proses sosialisasi, internalisasi, aktualisasi, dan inkulturasi yang berlangsung pada semua kelompok kekerabatan, yang dimulai dari keluarga inti (abbatireng) sampai pada kelompok yang paling besar dan luas (ampijangeng). Hal ini diperlukan mengingat tempat pengembangan individu menjadi pribadi yang mantap serta bertanggung jawab dimulai dari keluarga. Sejak lahir sampai usia dewasa, individu dibina dan dikembangkan sifat sifat keberanian, kejujuran, disiplin diri, serta tanggung jawabnya. Dengan demikian, ia akan berkembang menjadi pribadi yang tidak saja mengurangi konfik akan tetapi dapat menjadi media pen'yelesaian konflik baik dalam lingkungan keluarga, kelompok kekerabatan maupun di luar keluarga atau kelompok kekerabatan.

\section{KESIMPULAN}

Berdasarkan pembahasan terdahulu disimpulkan sebagai berikut:

1. Aspek pendidikan keluarga dalam pembentukan wija na bati sebagai' bagian dari sistem kekerabatan yanga pada masanya mampu membina pendidikan kepribadian keluarga yang baik namun pada saat ini fungsinya hanya sebagai simbol kekerabatan yang hanya mengikat secara internal kekerabatannya (keluarga inti) dan belum mampu secara efektif sebagai sarana pem- 
bentukan pendidikan kepribadian individual (bukan keluarga inti) yang mampu menciptakan kualitas individual yang dapat mendukung sistem sosial masyarakat Bugis Bone yang harmonis.

2. Konsep kepemimpinan yang dimiliki Orang Bugis Bone (konsep Ajjoareng) yang merupakan warisan budaya masyatakat Bugis Bone pada masanya mampu ${ }_{4}$ melahirkan kepemimpinan yang berkualitas, namun saat ini belum mampu berperan sebagai pranata sosial yang dapat menjadi sarana pembentukan pemimpin yang akuntabel dan respons'if guna terwujudnya masyarakat yang harmonis.

3. Pembentukan kualitas masyarakat melalui nilainilai dan norma-norma kekerabatan orang Bugis Bone pada masanya mampu membentuk kualitas masyarakat yang baik, namun saat ini berkurang peranannya sebagai pranata sosial yang mampu menjadi sarana pembentukan kualiatas masyarakat yang mendukung kehidupan sosial yang harmonis.

4. Peranan sejarah dan budaya orang Bugis Bone sampai sebagai warisan kebudayaan merupakan

\section{DAFTAR PUSTAKA}

Abu Hamid. 2002. Budaya Politik dan Kepemimpinan di Sulawesi Selatan. Makassar: Dinas Kebudayaan dan Pariwisata Sulawesi Selatan.

Kaplan David, 2002. Teori Budaya Jakarta: Pustaka Pelajar.

Koentjaraningrat, 1980. SejarahTeoriAntropologi I. Jakarta UI Press.

Koentjaraningrat, 1990. Pengantar Ilmu Antropologi. Jakarta: Rineka Cipta.

Lauer, Robert H 1993. Persfektif Tentang Perubahan Sosial. Rineka Cipta.

Linton, Ralph 1945. The Culture Background ofPesonality. New York: Appleton-Century-Crofts. prestasi peradaban yang didalamnya sarat dengan nilai dan norma kehidupan yang mempunyai potensi yang mampu membentuk suatu sistem sosial yang harjnonis, namun dalam perkembangannya pengaruhnnya berkurang karena sampai saat ini belum dapat menjadi sarana yang efektif untuk menciptakan kualitas individual dan kualitas sosial menuju terciptanya hubunganhubungan sosial yang harmonis disebabkan karena nilai-nilai atau norma-norma sistem kekerabatan kurang difungsikan secara maksimal dalam kehidupan sehari-hari oleh komunitasnya.

\section{Ucapan Terima Kasih}

Saya mengucapkan terima kasih kepada pengelola jurnal Al Qalam atas publikasi hasil riset ini. Ucapan terima kasih juga saya sampaikan kepada semua informan dalam penelitian ini, karena tanpa informasi dari mereka tulisan ini tidak ada artinya. Selain itu, ucapan terima kasih kepada Dekan dan rekan-rekan dosen pada Fakultas Ekonomi dan Ilmu Sosial Universitas Negeri Makassar atas kebersamaannya selama ini, semoga kerjasama dan kebersamaan selama itu dapat tetap terjaga.

Mappangara, Suriadi, 2004. Kerajaan Bone dalam Sejarah Politik Sulawesi Selatan Abad XIX, Dinas Kebudayaan dan Pariwisata Provinsi Sulawesi Selatan, Makassar.

Mattulada, 1975. Latoa : Suatu Lukisan Analitis terhadap Antropologi-Politik Orang Bugis, Disertasi, Universitas Indonesia, Jakarta.

Pelras, Cristian, 2006. Manusia Bugis Jakarta: Forum Jakarta Paris.

Sumaatmadja, H.Nursid 2000. Manusia dalam Konteks Sosial Budaya dan Lingkungan Hidup. Alfabeta: Bandung. 